\title{
PERBEDAAN HASIL BELAJAR MEMBACA PEMAHAMAN MENGGUNAKAN STRATEGI DRA (DIRECTED READING ACTIVITY) DENGAN STRATEGI KONVENSIONAL PADA SISWA KELAS XI SMA NEGERI 9 KOTA BENGKULU
}

\author{
'Sang Ayu Nyoman Putri Sri Asih; ${ }^{2}$ Syukri Hamzah; ${ }^{3}$ Gumono \\ 1,2,3 Universitas Bengkulu
}

\begin{abstract}
Abstrak
Penelitian ini bertujuan untuk mendeskripsikan perbedaan hasil belajar membaca pemahaman mengunakan strategi DRA (Directed Reading Activity) dengan strategi konvensional pada siswa kelas XI SMA Negeri 9 Kota Bengkulu. Metode yang digunakan dalam penelitian ini adalah komparasi. Pengambilan sampel penelitian ini menggunakan teknik purposive sampling yaitu sebanyak 27 siswa kelompok 1 dan 27 siswa kelompok 2. Instrumen penilitian berupa tes objektif (pilihan ganda). Teknik analisis data menggunakan uji-t. Hasil perhitungan diperoleh bahwa (1) hasil belajar kemampuan membaca pemahaman menggunakan strategi DRA (Directed Reading Activity) siswa kelas XI SMA Negeri 9 Kota Bengkulu diperoleh rata-rata (posttest) sebesar 78,52 kategori baik dan (2) hasil belajar kemampuan membaca pemahaman dengan strategi konvensional siswa kelas XI SMA Negeri 9 Kota Bengkulu dengan rata-rata sebesar 68,52 kategori cukup, dan (3) terdapat perbedaan kategori penguasaan pemahaman. Penerapan strategi DRA (Directed Reading Activity) dapat meningkatkan pemahaman reorganisasi siswa dengan baik dan siswa lebih aktif.
\end{abstract}

Korespondensi: sangayuputri2@gmail.com

Kata Kunci: strategi, pembelajaran, membaca, pemahaman

\section{Abstract}

This study is intended to describe the differences of learning result of reading comprehension using DRA (Directed Reading Activity) strategy with conventional strategy on eleventh grade students of Senior High School Number 9 Bengkulu City. The method used in this study is comparative. This study uses purposive sampling technique which consist of 27 students in group 1 and 27 students in group 2. The research instrument is objective test (Multiple choices). The data analysis technique uses T-Test. The calculation result is (1) the average (posttest) of the learning result of reading comprehension skill using DRA (Directed Reading Activity) strategy on the eleventh grade students of Senior High School Number 9 Bengkulu City is 78,52 as good category, (2) the average of the learning result of reading comprehension skill with conventional strategy on the eleventh grade students of Senior High School Number 9 Bengkulu City is 68,52 as sufficient category, and (3) there is significant difference of understanding mastery. The implementation of DRA (Directed Reading Activity) strategy could improve the students' reorganization understanding well and the students were more active.

Keywords: strategy, learning, reading

\section{PENDAHULUAN}

Bahasa merupakan suatu hasil kebudayaan yang mestinya dipelajari dan diajarkan. Melalui bahasa kebudayaan dapat dibentuk, dibina, dan dikembangkan serta dapat diturunkan 
sebagai suatu warisan budaya kepada generasi-generasi mendatang. Bahasa memungkinkan manusia dapat memikirkan suatu permasalahan secara teratur, dan berkelanjutan. Sebaliknya, tanpa adanya bahasa peradaban manusia tidak dapat berkembang dengan baik.

Bahasa memegang peranan penting dalam kehidupan sehari-hari karena bahasa merupakan alat komunikasi antar manusia. Secara luas dapat dikatakan bahwa komunikasi adalah suatu proses pengiriman dan penerimaan pesan yang pasti terjadi sewaktu-waktu. Komunikasi dapat berbentuk lisan dan tulisan, kedua bentuk komunikasi tersebut sangat berhubungan erat karena sifat penggunaannya yang saling berkaitan dalam bahasa.

Ada empat keterampilan dalam pembelajaran bahasa Indonesia yaitu aspek memyimak, berbicara,membaca, menulis. Keempat aspek tersebut saling berhubungan dan saling mempengaruhi satu sama lain dalam pengajaran bahasa.Keterampilan membaca dan menyimak merupakan kegiatan berbahasa yang bersifat reseptif, sedangkan keterampilan berbicara dan menulis merupakan kegiatan berbahasa yang bersifat produktif. Dari keempat aspek tersebut keterampilan membaca dianggap paling sulit sehingga membutuhkan pengajaran yang mampu miningkatkan kemampuan membaca terutama membaca dengan tujuan memahami isi bacaan. Tarigan (2008) mendefinisikan membaca adalah suatu proses yang dilakukan serta dipergunakan oleh pembaca untuk memperoleh pesan yang hendak disampaikan oleh penulis melalui media kata-kata/ bahasa tulis.

Sumadayo (2011:4) mendefinisikan membaca adalah suatu kegiatan interaktif untuk memetik serta memahami arti atau makna yang terkandung di dalam bahasa tulis. Disamping itu, membaca juga merupakan suatu proses yang dilakukan serta dipergunakan oleh pembaca untuk memperoleh pesan yang hendak disampaikan oleh penulis melalui media kata-kata atau bahasa tulis. Membaca Pemahaman merupakan kegiatan membaca untuk memperoleh pemahaman secara menyeluruh yang dilakukan oleh seseorang dengan menghubungkan pengetahuan awal yang dimiliki pembaca dengan pengetahuan baru yang diperoleh saat membaca.Dalman (2013:5) mendefenisikan membaca merupakan suatu kegiatan atau proses kognitif yang berupaya untuk menemukan berbagai informasi yang terdapat dalam tulisan. Pada dasarnya kegiatan membaca bertujuan untuk mencari dan memperoleh pesan atau memahami makna melalui bacaan. Tujuan membaca tersebut akan berpengaruh pada jenis bacaan yang dipilih. Jenis bacaan yang dimaksud ialah bacaan fiksi atau nonfiksi. Oka (1983:17) menjelaskan membaca sebagai proses pengolahan bacaan secara kritis-kreatif yang dilakukan dengan tujuan memperoleh pemahaman yang bersifat menyeluruh tetang bacaan itu, dan penilaian terhadap keadaan, nilai, fungsi, dan dampak bacaan itu.

Somadayo (2011:19) mendefinisikan membaca pemahaman pada hakikatnya adalah suatu proses membangun pemahaman terhadap wacana tulis. Proses ini terjadi dengan menjodohkan atau menghubungkan skemata pengetahuan dan pengalaman yang telah dimiliki sebelumnya dengan isi informasi dalam wacana sehingga terbentuk pemahaman terhadap wacana yang dibaca. Teori Taksonomi Barret membedakan lima kriteria yang dapat digunakan untuk mengetahui seberapa jauh tingkat pemahaman siswa dalam membaca yaitu (1) Pemahaman Harfiah (2) Pemahaman Reorganisasi (3) Pemahaman Inferensial (4) Pemahaman Evaluasi (5) Pemahaman Apresiasi. Rahim (2005:44) mendefenisikan Strategi (Directed Reading Activity) adalah suatu strategi yang digunakan untuk memperluas dan memperkuat kemampuan membaca siswa. Strategi 


\section{Sang Ayu Nyoman Putri Sri Asih; Syukri Hamzah; Gumono}

DRA (Directed Reading Activity) mempunyai lima komponen yaitu (1) Motivasi dan pengembangan latar belakang (2) membaca cerita secmara langsung (dalam hati dan bersuara) (3) strategi atau kegiatan yang membangun keterampila (4) latihan tindak lanjut (5) kegiatan-kegiatan pengayaan.

Kelebihan menggunakan strategi pembelajaran DRA (Directed Reading Activity) adalah siswa mempunyai tujuan membaca yang jelas dengan menghubungkan berbagai pengetahuan yang telah dipunyai siswa sebelumnya untuk membangun pemahaman sebelum dan sesudah membaca. Kelemahan menggunakan strategi DRA (Directed Reading Activity) adalah kurang memperhatikan keterlibatan siswa berfikir tentang bacaan.

Abdul (2013:165) mendefinisikan strategi pembelajaran konvensional sebagai pembelajaran dalam konteks klasikal yang sudah terbiasa dilakukan yang sifatnya berpusat pada guru, sehingga pelaksanaannya kurang memperhatikan keseluruhan situasi belajar (non belajar tuntas). Karakteristik pembelajaran konvensional yaitu proses pembelajaran dilakukan dengan menyampaikan materi pelajaran secara verbal, biasanya materi pelajaran yang disampaikan adalah materi pelajaran yang sudah jadi, seperti data atau fakta. Konsep-konsep tertentu yang harus dihapal sehingga tidak menuntut siswa untuk berpikir ulang. Tujuan utama pembelajaran adalah penguasaan materi pelajaran itu sendiri.

Membaca pemahaman merupakan salah satu aspek kemampuan bahasa yang harus dikuasai oleh siswa sekolah. Melalui kegiatan ini siswa dapat memperoleh berbagai informasi secara aktif reseptif. Maksudnya, dengan memiliki kemampuan membaca pemahaman yang tinggi, diharapkan siswa dapat memperoleh berbagai informasi dalam waktu yang relatif singkat. Kegiatan pembelajaran membaca di sekolah perlu memfokuskan pada aspek kemampuan memahami isi bacaan. Siswa perlu dilatih untuk memahami sebuah teks bacaan. Seorang guru Bahasa Indonesia harus mengajarkan kepada siswa cara membaca yang baik agar dapat memahami isi bacaan dengan tepat.

Berdasarkan hasil observasi dan wawancara dengan guru Bahasa Indonesia di SMA Negeri 9 Kota Bengkulu diperoleh keterangan bahwa saat ini siswa kelas XI masih banyak yang belum mampu melakukan kegiatan membaca pemahaman dengan baik, siswa mengalami kesulitan dalam berkonsentrasi, siswa tidak mampu menentukan tujuan membacanya. Masih banyak siswa yang setelah membaca bahan bacaan tidak dapat menemukan pesan atau informasi yang tepat, bahkan memerlukan pengulangan membaca beberapa kali. Permasalahan tersebut membuat peneliti ingin menerapkan strategi (Directed Reading Activity) yang dianggap mampu untuk meningkatkan hasil belajar membaca pemahaman teks narasi siswa. Peneliti merumuskan masalah penelitian ini yaitu Apakah terdapat perbedaan prestasi membaca pemahaman siswa kelas XI SMA Negeri 9 Kota Bengkulu dengan penerapan strategi DRA (Directed Reading Activity) dan strategi konvensional terhadap teks narasi?

Tujuan penelitian ini yaitu untuk mendeskripsikan perbedaan hasil belajar membaca pemahaman siswa kelas XI SMA Negeri 9 Kota Bengkulu dengan penerapan strategi DRA (Directed Reading Activity) dan strategi konvensional terhadap teks narasi. Hasil penelitian ini diharapkan dapat bermanfaat untuk memperkaya keilmuan yang terkait dengan proses pembelajaran membaca pemahaman dengan menggunakan strategi DRA (Directed Reading Activity).Siswa dapat memperoleh pengalaman belajar membaca pemahaman menggunakan strategiDRA (Directed Reading Activity) sehingga kemampuan membaca pemahaman dapat ditingkatkan. Guru dapat memilih pendekatan pembelajaran 
membaca pemahaman yang tepat dan dapat mengembangkan keterampilan guru dalam menerapkan pembelajaran dengan strategi DRA (Directed Reading Activity).

\section{METODE}

Metode yang digunakan pada penelitian ini adalah metode komparasi dengan pendekatan kuantitatif. Populasi penelitian ini adalah kelas XI SMA Negeri 9 Kota Bengkulu. Pengambilan sampel menggunakan teknik purposive sampling. Sampel dalam peneitian ini yaitu kelas XI IPS 1 dan kelas XI IPS 3. Keseluruhan sampel berjumlah 54 orang. Instrumen penelitian berupa tes (soal objektif). Validasi instrumen menggunakan expert validation jugment. Penelitian ini dilakukan di kelas XI SMA Negeri 9 Kota Bengkulu, yang beralamat di Jl. Wr Supratman No 15 Tugu Hiu Kota Bengkulu. Waktu penelitian dilakukan pada 20 Agustus 2018 sampai dengan 14 September 2018.

Data penelitian ini diperoleh dari hasil pretest dan posttest kemampuan membaca pemahaman teks narasi. Prosedur pelaksanaan penelitian adalah sebagai berikut penelitian diawali dengan melakukan pretest pada kelompok 1 yaitu kelompok yang akan mendapatkan pembelajaran membaca pemahaman dengan menggunakan strategi DRA (Directed Reading Activity) dan kelompok 2 yaitu kelompok yang akan mendapatkan pembelajaran membaca pemahaman dengan menggunakan strategi konvensional. Perlakuan pembelajaran sebanyak 2 pertemuan pada kelompok 1 sebanyak satu kali dan pada kelompok 2 sebanyak satu kali. Setelah pemberian perlakuan pada kedua kelompok peneliti melakukan pengambilan data (posttest) untuk mengukur keberhasilan strategi yang digunakan pada kedua kelompok. Setelah peneliti mendapatkan nilai pretest dan posttest kemampuan membaca pemahaman siswa, selanjutnya dilakukan analisis statistik untuk mengetahui perbedaan hasil belajar kemampuan membaca pemahaman antara kedua kelompok.

Teknik analisis data dalam penelitian ini yaitu dengan melakukan uji persyaratan analisis data dan uji hipotesis. Uji persyaratan analisis data terdiri atas uji normalitas dan homogenitas. Uji normalitas dan homogenitas dilakukan dengan bantuan program SPSS 19 for Windows. Setelah diperoleh hasil uji normalitas dan homogenitas maka dilakukan uji hipotesis dengan menentukan $r$ table dan nilai signifikansinya. Jika nilai signifikansi $>0.05$ maka tidak terdapat perbedaan hasil belajar membaca pemahaman antara kelompok 1 dan kelompok 2 dan jika nilai signifikansi $<0.05$ maka terdapat perbedaan hasil belajar membaca pemahaman antara kelompok 1 dan kelompok 2 .

Asumsi yang dirumuskan dan dikembangkan pada penelitian ini yaiyu membaca merupakan salah satu keterampilan berbahasa yang sangat penting untuk menyerap informasi. Penggunaan strategi pembelajaran mempengaruhi hasil belajar membaca pemahaman siswa.Strategi DRA (Directed Reading Activity) adalah salah satu strategi alternatif pengajaran membaca pemahaman. Hipotesis penelitian yang digunakan adalah: Ho : Tidak terdapat perbedaan hasil belajar membaca pemahaman siswa kelas XI SMA Negeri 9 kota Bengkulu yang menggunakan strategi DRA (Directed Reading Activity)dan siswa yang menggunakan strategi konvensional.

$\mathrm{H}_{1}$ : Terdapat perbedaan hasil belajar membaca pemahaman siswa kelas XI SMA Negeri 9 kota Bengkulu yang menggunakan strategi DRA (Directed Reading Activity) dan siswa yang menggunakan strategi konvensional.

\section{HASIL DAN PEMBAHASAN}




\section{Sang Ayu Nyoman Putri Sri Asih; Syukri Hamzah; Gumono}

\section{Hasil}

Data yang diperolah dalam penelitian ini berupa hasil tes. Tes yang digunakan berupa pretest dan posttest. Data diperoleh melalui tes objektif dari teks narasi yang masing-masing memiliki sebanyak 10 jumlah soal dengan 5 alternatif jawaban. Diberikan kepada 54 siswa, yang terdiri atas 27 siswa kelompok 1 (XI IPS 1) yang menggunakan strategi DRA (Directed Reading Activity dan 27 siswa kelompok 2 (XI IPS 3) yang menggunakan strategi konvensional pada pembelajaran membaca pemahan teks narasi. Dengan adanya data post test maka dapat dibuat perbandingan nilai rata-rata setiap kategori pemahaman yang diujikan, hal ini dapat menunjukkan perbandingan hasil pengusaan pemahaman dari kelompok yang menggunakan penerapan strategi DRA (Directed Reading Activity) dengan kelompok yang menggunakan penerapan strategi konvensional pada proses pembelajaran.

Di bawah ini adalah tabel perbandingan nilai rata-rata pre test dan post test kedua kelompok.

Tabel 1 Perbandingan Nilai Rata-Rata Pretest dan Posttest Kelompok 2

\begin{tabular}{ccccc} 
Kelompok & Pre Test & Kategori & Post Test & Kategori \\
\hline $\begin{array}{c}2 \\
\text { (Konvensional) }\end{array}$ & 57,78 & Cukup & 68,52 & cukup \\
& & & & \\
\hline
\end{tabular}

Tabel 2 Perbandingan Nilai Rata-Rata Pre-Test dan Post Test Kelompok 1

\begin{tabular}{ccccc}
\hline Kelompok & Pre Test & Kategori & Post Test & Kategori \\
\hline 1 & & & & \\
$\begin{array}{l}\text { (Directed } \\
\text { Reading } \\
\text { Activity) }\end{array}$ & 58,52 & Cukup & 78,52 & Baik
\end{tabular}

Berdasarkan tabel di atas maka dapat disimpulkan bahwa terjadi sedikit peningkatan nilai rata-rata hasil belajar membaca pemahaman teks narasi setelah menggunakan strategi konvensional. Rata-rata nilai pretest yaitu 57,78 kategori cukup dan rata-rata nilai posttest yaitu 68,52 kategori cukup. Terjadi peningkatan nilai rata-rata namun tidak signifikan dan ditak terjadi peningkatan kategori. Hasil ini menunjukkan bahwa strategi konvensiona tidak efektif dalam meningkatkan pemahaman siswa. Sedangkan terjadi peningkatan nilai rata-rata hasil belajar membaca pemahaman teks narasi setelah menggunakan strategi DRA (Directed Reading Activity. Rata-rata nilai pretest yaitu 58,52 kategori cukup dan rata-rata nilai posttest yaitu 78,52 kategori baik. Terjadi peningkatan nilai rata-rata dan kategori. Hasil ini menunjukkan bahwa strategi DRA (Directed Reading Activity) efektif dalam meningkatkan pemahaman siswa. Setelah diperoleh data pretest dan posttest selanjutnya dilakukan uji statistis dengan menggunakan bantuan SPSS 19 for Windows. 


\section{Uji Persyaratan Analisis}

\section{Hail Uji Normalitas}

Uji normalitas dilakukan untuk mengetahui data berdistribusi normal atau tidak. Berdasarkan uji normalitas pada hasil pretest kedua kelompok diperoleh hasil kelompok 1 signifikansinya 0,064 menunjukkan bahwa data berdistribusi normal karena signifikansinya $0,064>0,05$. Sedangkan, hasil pretest kelompok 2 signifikansinya $0,074 \mathrm{Hal}$ itu menunjukkan bahwa data berdistribusi normal. Data posttest kelompok 1 signifikansinya 0,064 sedangkan data hasil posttest kelompok 2 signifikansinya 0,064 . Hal itu menunjukkan bahwa data berdistribusi normal karena signifikansinya 0,064>0,05. Sehingga dapat disimpulkan data berdistribusi normal.

2. Hasil Uji Homegenitas

Uji homogenitas dilakukan untuk mengetahui data hasil kedua kelompok memiliki tingkat varian data yang sama atau tidak. Data yang akan diuji homogenitasnya adalah data hasil pretest kelompok 1 dan kelompok 2. Kriteria pengambilan keputusan adalah jika signifikansinya lebih dari 0,05 . Hasil uji homogenitas data pretest menunjukkan bahwa tingkat signifikansinya adalah 0,651 . Maka dengan hasil uji homogenitas tersebut dapat disimpulkan bahwa varian yang dimiliki kelompok 1 dan kelompok 2 tidak jauh berbeda dan cukup homogen karena 0,651>0,05. Hasil uji homogrnitas data posttest diperoleh tingkat signifikansinya adalah 1.000. Maka dengan hasil uji homogenitas tersebut dapat disimpulkan bahwa varian yang dimiliki kelompok 1 dan kelompok 2 tidak jauh berbeda dan cukup homogen karena 1.000>0,05.

Berdasrkan hasil uji normalitas dan uji homogenitas dapat disimpulkan bahwa data dari kedua kelompok berdistribusi normal dan homogen. Kedua uji ini dilakukan guna memenuhi uji prasyarat analisis sebelum melakukan penghitungan dengan rumus $t$ test.

\section{Uji Hipotesis}

Uji hipotesis dengan menggunakan $t$-test bertujuan untuk mengetahui perbedaan nilai ratarata tes pemahaman bacaan antara kelompok 1 yang menggunakan strategi DRA (Directed Reading Activity) dengan kelompok 2 yang menggunakan strategi konvensional. Analisis data dengan t-test dilakukan pada hasil pretest dan posttest dari kedua kelompok menggunakan program SPSS 19. for Windows yaitu Independent Samples t test. Kriteria pengujian hipotesis yaitu:

1. Jika signifikansi $t$-test $>0,05$ maka $\mathrm{H}_{\circ}$ diterima, artinya tidak ada perbedaan penerapan strategi DRA (Directed Reading Activity) terhadap keterampilan membaca pemahaman teks narasi siswa kelas XI SMA Negeri 9 Kota Bengkulu.

2. Jika signifikansi $t$-test $<0,05$ maka $H_{0}$ ditolak atau $H_{1}$ diterima, artinya ada perbedaan penerapan strategi DRA (Directed Reading Activity) terhadap keterampilan membaca pemahaman teks narasi siswa kelas XI SMA Negeri 9 Kota Bengkulu.

Setelah uji persyaratan analisis dilakukan pada hasil pre test kedua kelompok maka selanjutnya dilakukan uji T-test untuk mengetahui kemampuan awal keterampilan membaca pemahaman teks narasi pada kedua kelompok. Hasil uji t-test pretest kelompok 1 dan kelompok 2 menunjukan bahwa nilai signifikansi $0,831>0,005$, maka $\mathrm{H}_{\mathrm{o}}$ diterima dan $\mathrm{H}_{1}$ ditolak. Sehingga dapat disimpulkan bahwa tidak terdapat perbedaan yang signifikan nilai rata-rata tes keterampilan membaca pemahaman kelompok 1 dan kelompok 2. Kedua kelompok mendapatkan hasil pretest yang relatif sama atau tidak 


\section{Sang Ayu Nyoman Putri Sri Asih; Syukri Hamzah; Gumono}

terdapat perbedaan kemampuan membaca pemahaman yang signifikan anatara kedua kelompok.

Hasil uji t-test posttest kelompok 1 dan kelompok 2 menunjukan nilai signifikansi 0,004<0,005, maka $\mathrm{H}_{1}$ diterima dan $\mathrm{H}_{\mathrm{o}}$ ditolak. Maka dapat disimpulkan bahwa terdapat perbedaan yang signifikan nilai rata-rata tes keterampilan membaca pemahaman kelompok 1 dan kelompok 2. Hasil penelitian pada kelompok 1 menunjukkan bahwa penggunaan strategi DRA (Directed Reading Activity) telah teruji dapat memberikan manfaat bagi siswa dalam pembelajaran membaca pemahaman sehingga terjadi kenaikan skor pada tes akhir (posttest) yang diberikan kepada siswa kelompok 1.

\section{PEMBAHASAN}

Kondisi awal hasil belajar membaca pemahaman kelompok 1 dan kelompok 2 dalam penelitian ini diketahui dengan melakukan tes awal (pretest) keterampilan membaca pemahaman teks narasi pada kedua kelompok. Kedua kelompok tersebut diberi tes yang sama yaitu mengerjakan pretest yang berupa tes objektif berjumlah 10 butir soal, masingmasing butir soal memiliki 5 alternatif jawaban. Setelah kedua kelompok melakukan tes, data skor yang diperoleh kedua kelompok dianalisis dengan menggunakan bantuan komputer program SPSS 19. Data pretest hasil belajar membaca pemahaman kelompok 1 dengan subjek sebanyak 27 siswa diperoleh skor tertinggi 80 dan skor terendah 40 . Hasil analisis statistik deskriptif skor pretest kelompok 1 diperoleh skor rerata sebesar 58,52, median 60, modus 60 dan standar deviasi sebesar 12,31. Data pretest membaca pemahaman kelompok 2 dengan subjek 27 siswa diperoleh skor tertinggi 80 dan skor terendah 40. Hasil analisis statistik deskriptif skor pretest kelompok 2 diperoleh skor ratarata sebesar 57,78, median 60, modus 60, dan standar deviasi 13,10. Dari hasil tersebut dapat diketahui bahwa skor tes hasil belajar membaca pemahaman kelompok 1 dan kelompok 2 setara atau ralatif sama.

Setelah mengetahui skor awal kedua kelas baik kelompok 1 maupun kelompok 2 tidak ditemukan perbedaan yang signifikan, kemudian kedua kelompok diberi perlakuan yang berbeda berupa pembelajaran membaca pemahaman dengan menggunakan strategi DRA (Directed Reading Activity) pada kelompok 1 dan pembelajaran membaca pemahaman dengan strategi konvensional pada kelompok 2, diperoleh skor rerata sebesar 58,52, median 60, modus 60 dan standar deviation sebesar 12,31. Data pretest membaca pemahaman kelompok 2 dengan subjek 27 siswa diperoleh skor tertinggi 80 dan skor terendah 40. Hasil analisis statistik deskriptif skor pretest kelompok 2 diperoleh skor ratarata sebesar 57,78, median 60, modus 60, dan standar deviasi 13,10. Dari hasil tersebut dapat diketahui bahwa skor tes hasil belajar membaca pemahaman kelompok 1 dan kelompok 2 setara atau ralatif sama. Hal ini sesuai dengan teori Hamzah B. Uno (2008:45) yang menyatakan strategi pembelajaran merupakan hal yang perlu diperhatikan guru dalam proses pembelajaran. Karena kemampuan guru dalam memilih dan menggunakan strategi pemebalajaran yang tepat dengan materi pembelajaran akan mempermudah siswa untuk memahami pembelajaran sehingga akan memberikan pencapaian hasil belajar yang lebih baik.

Tabel 3 Rata-rata Pencapaian Setiap Kategori Pemahaman

Kelompok Kategori Pemahaman


Perbedaan Hasil Belajar Membaca Pemahaman Menggunakan Strategi DRA...

\begin{tabular}{ccccc}
\hline & Harfiah & Reorganisasi & Inferensial & Evaluasi \\
\hline 1 & 24 & 48 & 81 & 59 \\
\hline 2 & 24 & 32 & 72 & 57 \\
\hline
\end{tabular}

Dari tabel nilai pencapaian setiap kategori pemahaman di atas maka dapat disimpulkan bahwa:

1. Pemahaman Harfiah

Setelah diberikan penerapan strategi DRA (Directed Reading Activity) pada kelompok 1 dan strategi konvensional pada kelompok 2, ternyata hasil pada kategori pemahaman harfiah relatif sama.

2. Pemahaman Reorganisasi

Setelah diberikan penerapan strategi DRA (Directed Reading Activity) pada kelompok 1 dan startegi konvensional pada kelompok 2 ternyata menunjukkan hasil yang berbeda. Kelompok 1 dapat menguasai pemahaman reorganisasi lebih baik dibandingkan dengan kelompok 2. Hal ini ditunjukkan dari hasil pemahaman reorganisasi kelompok 1 yang lebih tinggi dibandingkan dengan kelompok 2.

3. Pemahaman Inferensial

Setelah diberikan penerapan strategi DRA (Directed Reading Activity) pada kelompok 1 dan strategi konvensional pada kelompok 2 ternyata menunjukkan hasil yang berbeda. Kelompok 1 dapat menguasai pemahaman reorganisasi lebih baik dibandingkan dengan kelompok 2. Hal ini ditunjukkan dari hasil pemahaman inferensial kelompok 1 yang lebih tinggi dibandingkan dengan kelompok 2.

4. Pemahaman Evaluasi

Setelah diberikan penerapan strategi DRA (Directed Reading Activity) pada kelompok 1 dan strategi konvensional pada kelompok 2, ternyata hasil pada kategori pemahaman evaluasi relatif sama.

Hal ini menunjukkan bahwa penerapan strategi DRA (Directed Reading Activity) relatif tidak memberikan pengaruh yang besar pada pengusaan pemahaman harfiah. Akan tetapi, terlihat perbedaan yang cukup signifikan pada pemahaman reorganisasi. Sedangkan, pada pemahaman inferensial dan pemahaman evaluasi perbedaan prestasi tidak terlalu besar walaupun cukup signifikan. Dengan adanya perbedaan jumlah nilai pencapaian setiap kategori pemahaman maka dapat disimpulkan bahwa kelompok dengan penerapan strategi DRA (Directed Reading Activity) memiliki kemampuan pemahaman reorganisasi lebih baik dibandingkan kelompok dengan menggunakan strategi konvensiaonal. Dengan demikian, penerapan strategi DRA (Directed Reading Activity) mampu meningkatkan pemahaman reorganisasi siswa dengan baik. Selain perbedaan pada pengusaan kategori pemahaman penerapan strategi DRA (Directed Reading Activity). juga memberikan pengaruh pada sikap dan keaktifan siswa di dalam kelas.

Dari hasil pengamatan dalam pembelajaran di kelas, siswa yang mendapat pembelajaran membaca pemahaman dengan menggunakan strategi DRA (Directed Reading 


\section{Sang Ayu Nyoman Putri Sri Asih; Syukri Hamzah; Gumono}

Activity) lebih aktif dalam pembelajaran. Siswa lebih antusias ketika pembelajaran membaca berlangsung. Sikap antusias ini ditunjukkan siswa melalui aktif merespon penjelasan guru dengan menanyakan hal-hal yang tidak dimengerti. Siwa sangat fokus ketika membaca teks yang diberikan oleh guru. Sebelum kegiatan membaca, siswa sudah aktif dalam kegiatan berdiskusi di kelas untuk memprediksi dan menghubungkan judul bacaan yang diberikan dengan pengetahuan yang dimiliki oleh siswa. Setelah kegiatan membaca, siswa juga aktif untuk mengembangkan keterampilan yaitu membuat mind mapping berdasarkan dari berbagai informasi yang mereka peroleh dari teks yang dibaca. Siswa yang memperoleh pembelajaran membaca pemahaman dengan strategi konvensional cenderung lebih banyak diam ketika proses pembelajaran. Kegiatan siswa di kelas setelah memperoleh bacaan hanya menjawab pertanyaan yang diberikan oleh guru. Pembelajaran membaca menjadi kurang efektif dan kurang menarik sehingga pemahaman terhadap teks bacaan menjadi kurang maksimal. Setelah kedua kelompok diberi perlakuan yang berbeda, kemudian dilaksanakan posttest untuk dapat mengetahui skor akhir posttest kelompok 1 diperoleh skor rata-rata sebesar 78,52 sedangkan skor rerata data posttest kelompok 2 sebesar 68,52. Dari hasil skor rerata tersebut dapat dilihat bahwa skor rerata data posttest kelompok 1 lebih tinggi dari pada skor rerata kelompok 2.

Perbedaan hasil belajar membaca pemahaman antara kelompok 1 dan kelompok 2 juga dilihat dari hasil yang diperoleh berdasarkan analisis dengan menggunakan uji-t. Analisis dilakukan dengan menggunakan bantuan komputer program SPSS 19. Hasil analisis diperoleh t hitung sebesar 2.984 dengan df sebesar 52 dan nilai signifikansinya sebesar 0,004 lebih kecil dari pada taraf signifikansi 0,05 (5\%). Hasil perhitungan tersebut dapat disimpulkan bahwa terdapat perbedaan kemampuan membaca pemahaman antara kelompok 1 dan kelompok 2.

Hasil penelitian pada kelompok 1 menunjukkan bahwa penggunaan strategi DRA (Directed Reading Activity) telah teruji dapat memberikan manfaat bagi siswa dalam pembelajaran membaca pemahaman sehingga terjadi kenaikan skor pada tes akhir (posttest) yang diberikan kepada siswa kelompok 1. Manfaat yang diperoleh siswa pada kelompok 1 terlihat pada beberapa hal, diantaranya adalah membantu siswa untuk menemukan masalah pada bacaan. Manfaat lain yang diperoleh siswa, yaitu membantu siswa untuk menggali rasa ingin tahu. Langkah-langkah kegiatan pembelajaran yang digunakan dalam strategi DRA (Directed Reading Activity) membantu siswa mencapai pemahaman yang mendalam terhadap isi bacaan. Pernyataan tersebut menunjukkan bahwa terdapat perbedaan kemampuan membaca pemahaman yang signifikan antara siswa yang mendapat pembelajaran membaca pemahaman dengan menggunakan strategi DRA (Directed Reading Activity) dan siswa yang mendapat pembelajaran membaca pemahaman menggunakan strategi konvensional. Hal ini menunjukkan bahwa tujuan penelitian ini tercapai.

\section{PENUTUP}

\section{Kesimpulan}

Hasil penelitian dan pembahasan dapat disimpulkan sebagai berikut (1) hasil belajar kemampuan membaca pemahaman menggunakan strategi DRA (Directed Reading Activity) siswa kelas XI SMA Negeri 9 Kota Bengkulu diperoleh rata-rata (post test) sebesar 78,52 kategori baik dan (2) hasil belajar kemampuan membaca pemahaman dengan strategi konvensional siswa kelas XI SMA Negeri 9 Kota Bengkulu dengan rata-rata sebesar 68,52 
kategori cukup. Serta (3) terdapat perbedaan kategori penguasaan pemahaman.Penerapan strategi DRA (Directed Reading Activity) meningkatkan pemahaman reorganisasi siswa dengan baik. Sedangkan strategi konvensional tidak. Perbedaan hasil kedua kelompok terjadi karena proses belajar yang berbeda. Kelompok yang menggunakan strategi DRA (Directed Reading Activity) lebih aktif saat kegiatan pembelajaran berlangsung hal ini karena pembelajaran berpusat pada siswa (studen center). Sedangkan kelompok yang menggunakan strategi konvensional cenderung lebih pasif karena pembelajaran hanya berpusat pada guru (teacher center).Secara keseluruhan dapat disimpulkan bahwa pembelajaran membaca pemahaman dengan strategi DRA (Directed Reading Activity) dapat meningkatkan kemampuan siswa dalam memahami sebuah teks narasi. Selain itu dapat lebih meningkatkan aktivitas belajar siswa di kelas.

\section{SARAN}

1. Hasil belajar siswa dipengaruhi oleh pemilihan strategi pembelajaran yang tepat. StrategiDRA (Directed Reading Activity)) ini dapat dijadikan salah satu alternatif strategi belajar dalam pembelajaran Bahasa Indonesia terutama pada sub materi membaca pemahaman.

2. Siswa harus mempertahankan dan meningkatkan hasil belajar membaca pemahaman teks narasi. Guru diharapkan untuk selalu memperhatikan hasil belajar siswa dan dapat berperan aktif dalam meningkatkan kemampuan membaca pemahaman siswa dengan memilih dan menerapkan strategi pembelajaran yang tepat. Karena penerapan strategi pembelajaran yang tepat akan memperoleh hasil belajar yang lebih baik.

3. Siswa harus lebih meningkatkan konsentrasi dan motivasi dalam belajar sertaberperan aktif dalam kegitan pembelajaran.

\section{DAFTAR PUSTAKA}

Dalman. 2013. Keterampilan Membaca. Jakarta: Rajawali Pers.

Majid, A. 2013. Strategi Pembelajaran. Bandung: PT. Remaja Rosdakarya.

Oka, G. N. 1983. Pengantar Membaca dan Pengajarannya. Surabaya: Usaha Nasional.

Somadayo, S. 2011. Satategi dan Te knik Pembelajaran Membaca. Yogyakarta: Graha Ilmu.

Sugiono. 2014. Cara Mudah Menyusun Skripsi, Tesis danDisertasi. Bandung: ALFABETA.

Sujarweni, W. 2014. Metodologi Penelitian. Yogyakarta: Pustakabarupress.

Tarigan, H. G. 1994. Membaca Sebagai Suatu Keterampilan Berbahasa. Bandung: Angkasa. 